\title{
Measuring of Technological Capabilities in Technology Transfer (TT) Projects
}

\author{
Roshartini Omar ${ }^{1}$, Roshana Takim ${ }^{2} \&$ Abdul Hadi Nawawi ${ }^{2}$ \\ ${ }^{1}$ Faculty of Technology Management and Business, Department of Construction Management, University Tun \\ Hussein Onn Malaysia (UTHM), Batu Pahat, Johor, Malaysia \\ ${ }^{2}$ Centre of Postgraduate Studies, Faculty of Architecture, Planning \& Surveying, University Technology MARA \\ (UiTM), Shah Alam, Malaysia \\ Correspondence: Roshartini Omar, Faculty of Technology Management and Business, Department of \\ Construction Management, University Tun Hussein Onn Malaysia (UTHM), Batu Pahat, Johor, Malaysia. Tel: \\ 60-13-936-0507.E-mail: shartini@uthm.edu.my
}

Received: July 30, 2012 Accepted: September 25, 2012 Online Published: November 30, 2012

doi:10.5539/ass.v8n15p211 URL: http://dx.doi.org/10.5539/ass.v8n15p211

\begin{abstract}
Technology Transfer (TT) projects involve the cross-boarder transfer of technology with the main purpose of enhancing the local technological capabalities in response to a changing economic environment. Technological capability refers to an organisation's capacity to deploy, develop and utilise technological resources and integrate them with other complementary resources to supply the differentiated products and services. Technological capability is embodied not only in the employees' knowledge and skills and the technical system, but also in the managerial system, values and norms. Therefore, the phenomena of TT projects occur at the macro and micro level in organisations. The main problem identified in international TT is the lack of managerial capabilities. The common question is how to measure technological capabilities from the perspective of technology receivers.

The objective of this paper is to measure the level of technological capabilities in TT projects. The empirical research was undertaken by means of Case Studies using semi-structured interviews with Human Resource Management officers from six (6) Category of G7 contractor companies in Malaysia. . A total of six organisations (currently engaged in overseas projects) were involved representing $100 \%$ response rate. The results were analysed using of NVivo software version 8.

The findings revealed that, three components for measuring the level of technological capabilities in TT projects are production performance (i.e., construction cost, time, product quality, safety, productivity, profitability, and client satisfaction); technology utilisation (i.e., labour force and organisation \& management); and firm's/orgaisation's capability (i.e., tools \& equipment, research input and development output). These measurements could be used as a guideline for measuring technological capabilities in TT projects for construction organisations.
\end{abstract}

Keywords: technology transfer (TT) projects, Malaysia, technological capabilities

\section{Introduction}

Technological capabilities are the information and skills, technical, managerial and institutional; that allow productive enterprises to utilize equipment and technology efficiently (Biggs et al. 1995). Technological capabilities comprise a much broader range of effort that every firm must itself undertake in order to absorb and build upon the knowledge that has to be utilized in production.

For instance, the success of TT (i.e., knowledge, skills and tools) to a developing country is through acquisition of equipment and operating instructions, patents, designs or blueprints. However, it does not ensure that technology will be properly used. Elements of a technology embedded in a process or equipment are accompanied by additional "tacit" elements, which the technology recipient must acquire (Biggs et al. 1995). Technological capability is more, than a simple sum of the education and training of a firm's employees. It includes the learning process undergone by individuals in the course of working in the organisations and the way in which the organisation combines and motivates individuals to function (Hoffman, 1989 cited in Biggs et al. 1995). This is in line with the opinion of Rosenberg and Firschtak (1985) who both define that technological 
capability as a process of accumulating technical knowledge or a process of organisational learning.

According to Kumar et al. (1999), technological capabilities can be assessed in terms of a firm's ability to identify its technological needs and to select the technology to fulfill the needs; to operate, maintain, modify and improve the selected technology, and; to promote technical learning. These may be transferred through training, personnel exchange, or managerial and technical support from suppliers (Bell, 1987). However, according to Cusumano and Elenkov (1994), this TT process would depend on whether firms can extract the most from the managerial, technical and other supports provided by suppliers and which local personnel are involved in the process.

Wei (1995) added that the more local employees are involved in the TT process, the more 'know-how' (i.e., knowledge and skills) capabilities are likely to accrue to the organisations. Strong linkages among departments within the organisations strengthen continuous and intensive contacts between functional and technically specialised groups which is essential for the cultivation of technological capabilities (Wallender, 1979; cited in Kumar et al. 1999). In short, learning capability could be acquired through a cumulative process of learning-by-doing, learning-by-using, learning-by-interacting and learning-by-searching (i.e., conducting in-house research) (Kumar et al. 1999).

Within commercial organisations, TT is intended to enable technology acquirers to manufacture a certain product or provide a particular service, thus the acquirers do not only recognise the value of technology and assimilate the knowledge, but also exploit and innovate it based on learning. Compared with TT that occurs within national borders, specific difficulties are encountered when a technology is transferred internationally.

Some of the problems are caused by the differences in strategies and capabilities, technological infrastructure, language, the level of economic development, culture and attitude between home and host countries, as well as high communication costs. In so far as technology is conceived as firm-specific, and to the extent that it is tacit and cumulative in nature, the transfer of technology involves significant resource costs, reflecting the problem of replicating knowledge across the boundaries of firms and countries. Thus the main difficulty of a TT is concerned with transmitting the tacit component of the technology.

For acquisition of technology, the process of assimilating the transfer of technology is best characterised as a complicated process of organisational learning wherein individuals and the organisation acquire the knowledge and skills necessary to effectively apply the technology (Ghang, 2010; Frichman and Kemerer, 1997). The organisational learning could be defined as a learning organisation that actively creates, captures, transfers, and mobilizes knowledge to enable it to adapt to a changing environment. At the firm level, changes often go hand in hand with changes in organisational capabilities. Technological capability is embodied not only in the employees' knowledge and skills and the technical system, but also in the managerial system and the values and norms, i.e., it cannot be developed independently of its other capabilities.

Given the above, various models of technological capabilities have been investigated from the literature. These models of technological capabilities are taken from different industries (manufacturing and construction). These models serve to enlighten the critical variables that are needed to mark successful transaction and practical issues in the TT processes. The purpose is to review the existing technological capabilities models from different industries in order to capture critical variables for successful transaction of technological capabilities of TT process via mega construction projects.

\section{Technological Capabilities Models}

Table 1 presents five types of technological capabilities models gathered from various researchers (i.e., Kumar et al. 1999; Smook \& Van Egmond, 2001; Schoenecker \& Swanson, 2002; Abu-Bakar, 2004; and Dutta et al. 2005) across industries. Each of the models will be discussed into further details below:

\subsection{Kumar Model of Technological Capabilities - Manufacturing Industry}

A conceptual model of technological capabilities developed by Kumar et al. (1999) covers forty-five Indonesian manufacturing firms in the garment, textile, electronics, and footwear industries that involved in TT projects. Both quantitative and qualitative data on TT projects were collected through a combination of personal interviews and a self-administered questionnaire. Kumar et al. (1999) have classified the measurements of technological capabilities into two categories: dependent and independent variables. The dependent variables is the mastery of technology in terms of operating the technology; maintaining the technology; repairing the technology (in case of a breakdown); making minor modifications to the technology; and maintaining product quality.

The independent variables however, consist of firm's R\&D spending; firm's planning and control of the 
technology acquisition; availability of technical personnel; duration of training programs; government role and mode of transfer used. The results revealed that the level of sophistication of the technology transferred is simple relative to the firms' existing technology. This is confirmed from the short duration of training provided by firms to their employees due to the existing employees' technological capabilities. However, the duration of training is depends on the employees' ability to absorb the knowledge (Minbaeva et al. 2003). The employees' ability relates to job related skills and educational level.

The strength of this model is that the overall concepts are simple but it is difficult to implement in most construction firms due to the unavailability of R\&D departments in most construction companies and duration of training also is not suitable variable to measure the employees' technological capabilities.

\subsection{Smook and Van Egmond Model of Technological Capabilities - Construction Industry}

Smook and van Egmond (2001) developed a model of technological capabilities for construction industry. The data were gathered from database. The model describes a study of the productivity and technological performance of construction projects executed by large scale and internationally operating construction companies in the Netherlands and in Japan. In this model, they focused on three important variables: production performance, technology utilisation and technological capability. The production performance could be measured by product quality, client satisfaction, safety, construction time and cost, productivity and profitability. Facets to measure technology utilisation are labour force and organisation \& management. The technological capabilities are the number and kind of equipment and tools, research input and development output. Developing a cutting edge technological capabilities and sustaining that capability is vital for construction companies.

To develop a certain unique specialty can help to be competitive in a certain niche market. Smook and van Egmond (2001) claimed that the problem in construction industry, a certain technological capabilities or specialty is often rapidly imitated or copied. The competition among construction players is required in research and development on an ongoing basis to make employees' technological capabilities sustained. In that case, policies to join forces with the competition with a kind of cooperation or companies are considered. The strength of this model is that the overall concepts are easily understood and very simple to implement.

Table 1. The measurements of technological capabilities in technology transfer (TT)

\begin{tabular}{|c|c|c|c|c|c|}
\hline Industry & Manufacturing & Construction & Manufacturing & Construction & Manufacturing \\
\hline Country & Indonesia & Netherlands \& Japan & $\begin{array}{l}\text { United State of America } \\
\text { (USD) }\end{array}$ & Malaysia & $\begin{array}{l}\text { United State of } \\
\text { America (USD) }\end{array}$ \\
\hline Author & Kumar et al. (1999) & $\begin{array}{l}\text { Smook \&Van Egmond } \\
(2001)\end{array}$ & $\begin{array}{l}\text { Schoenecker \& Swanson } \\
(2002)\end{array}$ & Abu Bakar (2003) & Dutta et al. (2005) \\
\hline \multirow[t]{2}{*}{ Sample } & Questionnaires \& interviews & Database & Questionnaires and Database & Questionnaires & $\begin{array}{l}\text { Database and } \\
\text { content analysis }\end{array}$ \\
\hline & -45 Indonesian manufacturing & construction & $\begin{array}{l}\text {-Pharmaceutical, Electronics } \\
\text { \& Chemical companies }\end{array}$ & $\begin{array}{l}-42 \text { Malaysian local } \\
\text { contractors }\end{array}$ & $\begin{array}{l}-64 \text { public traded } \\
\text { firms }\end{array}$ \\
\hline \multirow[t]{19}{*}{ Measurement } & Measured by: & Measured by: & Measured by: & Measured by: & Measured by: \\
\hline & Dependent variable & Production Performance & 1) Patents & Independent variables & 1) Technological \\
\hline & 1) Technological capabilities & 1) Product quality & -Number of company patents & 1) Financial & output \\
\hline & -Mastery of the technology in & 2) Client satisfaction & 2) R \& D budget & (profitability) & Resources \\
\hline & terms of operating the & (meeting the market & -Average annual research & 2) Capacity & (inputs) \\
\hline & technology & requirements) & budget & 3) Capability & -Cumulative R \& D \\
\hline & -Maintaining the technology & 3) Safety on construction & 3) Patent citation score & Sub-variables & expenditure \\
\hline & $\begin{array}{l}\text {-Repairing the technology in case } \\
\text { of a breakdown }\end{array}$ & $\begin{array}{l}\text { site } \\
\text { 4)Productivity }\end{array}$ & $\begin{array}{l}\text {-Relative frequency that a } \\
\text { firm's patents are cited in other }\end{array}$ & $\begin{array}{l}\text { 1) The experience in } \\
\text { TT project }\end{array}$ & $\begin{array}{l}\text {-Cumulative } \\
\text { marketing }\end{array}$ \\
\hline & $\begin{array}{l}\text {-Making minor modifications to } \\
\text { the technology, and }\end{array}$ & $\begin{array}{l}\text { 5) Profitability (profit } \\
\text { margin) }\end{array}$ & $\begin{array}{l}\text { patents } \\
\text { 4) New products }\end{array}$ & $\begin{array}{l}\text { 2) The number of TT } \\
\text { projects undertaken }\end{array}$ & $\begin{array}{l}\text { expenditure } \\
\text { 3) } R \& D \text { intensities }\end{array}$ \\
\hline & -Maintaining product quality & 6) Construction Cost & -Number of new drug & 3) Ownership & 4) Marketing \\
\hline & Independent variables & 7) Construction time & applications approved by the & 4) Resource factors & intensities \\
\hline & 1) $R$ \& D expenditure & Technology utilization & FDA & 5) The TT programme & \\
\hline & 2) Technical personnel & 1) Labor force & 5) Financial performance & 6) Technology as & \\
\hline & 3) Training & 2) Organization & -Composite index constructed & Knowledge & \\
\hline & -Duration (in days) of formal & Management & from six different financial & & \\
\hline & training per employee in & Technological Capability & measures & & \\
\hline & preparation of the transfer & $\begin{array}{l}\text { 1) Number and kind of } \\
\text { equipment and tools }\end{array}$ & & & \\
\hline & & 2) Research input & & & \\
\hline & & 3) Development output & & & \\
\hline
\end{tabular}




\subsection{Schoenecker and Swanson Model of Technological Capabilities - Manufacturing Industry}

The model by Schoenecker and Swanson (2002) presents indicators of firm technological capabilities for pharmaceuticals, electronics, and chemicals industries at United States of America. The data were collected from database. They examined the relationships between various indicators of firm technological capabilities between firm performances.

In this model, they focused on five (5) important variables: patents, $R \& D$ budget, patent citation score, new products and financial performance. Patents could be measured by numbers of company patents over the period 1975-1982. The R\&D budget is the average annual research budget. Patents citation score is the relative frequency that a firm's patents cited in other patents within 7 years (i.e., 1975-1982). The new product is the measured by the number of new products on 1965-1976 and financial performance is measured based index constructed from six different financial measures. In pharmaceutical industry, $R \& D$ intensity is significantly correlated with sales growth and operating profit margins. It may be possible that higher R\&D intensity resulted in more and better products and improved profitability. Better profitability may provide the firms with greater resources to expend. The model looks simple but is difficult to implement in most construction firms due to the unavailability of R\&D departments and patents of product in most construction companies and industry.

\subsection{Abu-Bakar Model of Technological Capabilities - Construction Industry}

Abu-Bakar (2004) proposes a theoretical model of absorptive capacity and technological capabilities for effectiveness of TT in projects. The data were gathered from 42 Malaysian construction companies by means of questionnaire to examine the relationships between independent and sub-variables. The independent variables are financial, capacity, and capability. The sub-variables however, consist of experience in TT projects; the number of TT projects undertaken; ownership; resource; TT programme and technology as knowledge. This model is comprehensive in nature, but one of the weaknesses of this model is that the variables are not focus based on production performance and technology utilisation as Smook and van Egmond (2001) model in construction industry and failed to focus on measuring of technological capabilities.

\subsection{Dutta Model of Technological Capabilities - Manufacturing Industry}

The model developed by Dutta et al. (2005) presents a framework for manufacturing industry. With database and content analysis data from manufacturers industry in United State of America, they illustrated the theory and measurements of firm's capabilities in the semiconductor and computer equipment industries. The sample consists of 64 publicly traded firms. For each firm in the study, they collected information pertaining to the resources available to R\&D domain of activity, and the output from the database within 1980-1998.

They identified four important variables which include: technological output, resources (cumulative R\&D expenditure and cumulative marketing expenditure), $R \& D$ intensities and marketing intensities. In their study, the limitations of their approach, as well as of its applicability, the model is not confined to any single level of analysis. The capabilities of project level are the other level of functional domains of activity (R\&D) that could be considered. The strength of this model is that it is comprehensive and yet simple to understand.

Given the above, most of the models, are stressing on measuring the technological capabilities of TT projects. Notwithstanding, the common focus on technological capabilities for firms: the results of the studies are depended upon the perspectives of each individual industry. In all the studies, the technological capabilities model developed by Smook and van Egmond (2001) seems to provide complete measurements of technological capabilities in TT projects particularly in construction industry. With the exception of the model developed by Abu-Bakar, the models developed by Dutta et al. (2005), Schoenecker and Swanson (2002) and Kumar et al. (1999) on the other hand, are comprehensive and yet simple to understand. A detailed analysis showed that those variables emerged from these models is applicable for the construction industry.

Hence, these models could be used as a guideline, in developing a propose framework for measuring technological capabilities in TT projects for construction organisations.

\section{Proposed Research Framework}

Figure 1 proposes a framework for measuring technological capabilities of TT projects in construction organisations. This has been developed based on integrating the various form of literature search and understanding of the information gathered by Kumar et al. (1999); Smook \& Van Egmond, (2001); Schoenecker \& Swanson, (2002); Abu-Bakar, (2004); and Dutta et al. (2005). Among others, the model developed by Smook \& van Egmond (2001) are inclined to construction industry and the most suitable in measuring levels of technological capabilities in TT projects. 


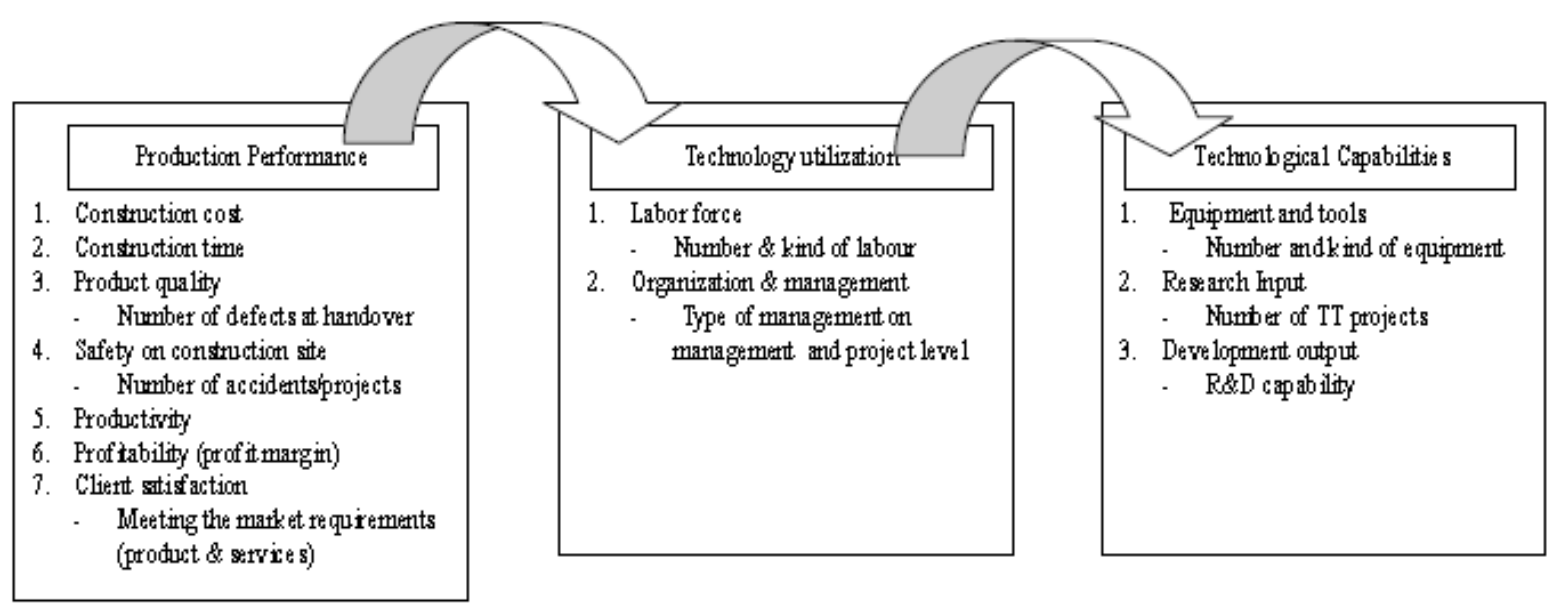

Figure 1. Propose of framework for measuring level of technological capabilities in TT projects

Source: Smook and van Egmond (2001)

Fundamentally, the proposed framework for measuring technological capabilities in TT projects starts with the understanding of three main components: production performance, technology utilisation and firms' capabilities. To measure the production performance, the critical variables included are construction cost (percentage difference estimated cost/actual cost), construction time (time/construction cost), product quality (number of defects at handover), safety (number of accidents), productivity (output/input), profitability (net profit margin and return on investment) and client's satisfaction (meeting the client requirement).

In addition to production performance, technology utilisation is another important component to be measured. Two main variables that are included in this component are labour force and organisation \& management. To measure the labour force, the number and kind of labour could be considered (management professional, skilled technical staff and skilled workers). Meanwhile organisation \& management variable is measured by type of procedures or policy of management employed in the company. Both of these variables could help companies to increase knowledge and skills of the employees.

The outcomes of production performance and technology utilisation would influence the measurement on the firm's capability in the form of tools and equipment, research input and development output. To measure the tools and equipments, the number and kind of imported equipment could be asked. Research input is measured by number of TT projects that the company had constructed, followed by, development output is measured based on the availability of R\&D capability in the company. Knowledge, skills and tools could be transferred and shared among employees and extensive intra-organisational communication is likely to contribute to employees' technological capabilities.

According to Biggs et al. (1995), technological capabilities are the information and skills, technical, managerial and institutional those allow productive enterprises to utilise equipment and technology efficiently. They added acquiring equipment and operating instructions, patents, designs or blueprints does not ensure that the technology will be properly used. Elements of technology emended in a process or equipment are accompanied by additional "tacit" elements, which the recipient must learn as well.

Taking into consideration of the above, the framework for measuring of technological capabilities in construction's organisations comprising production performance, technology utilisation and firm's capabilities which are strongly supported by construction cost, construction time, product quality, safety, productivity, profitability, client satisfaction, labour force, organisation \& management, tools \& equipment, development input and research output. The impact of TT on organisational capability however, could be measured via the level of technological capabilities of the companies/firms based on the proposed framework.

Considering the above framework of technological capabilities in TT projects, together with the proposed variables (i.e, production performance, technology utilisation, and firms capabilities), case studies were undertaken in six (6) Category of construction companies among six Human Resource officers. A document analysis was used for cross checking the information obtained prior final conclusion.

\section{Research Methodology}

The Case Studies by means of semi-structured interviews was undertaken within a period of 4 months (from 
December 2010-March 2011) with Human Resource Management officers from the six (6) Category of G7 contractor companies (A, B, C, D, E and F) in Malaysia. A total of six organisations (currently engaged in overseas projects) were involved representing $100 \%$ response rate. The case study research method used to collect the data (qualitative research techniques) aims to address the research questions of 'how' and 'why' in order to develop a framework of TT in mega construction projects in Malaysia. The face-to-face interviews were designed to gain a feedback in strengthening the understanding of technological capabilities in TT from the HR respondents' own experience. The interviews were recorded and transcribed verbatim for conceptual content analysis.

The interviews were conducted on an appointment basis. Each interview sessions started off with phrases of appreciation to the interviewees, brief personal introductions, followed by an explanation on the objective of the interviews and the relationship with the overall research being undertaken. Assurances of data confidentially were given and thus permission was granted for the conversations to be recorded. In undertaking this task, every effort was made to minimise the threats to validity and reliability of the data that can occur in qualitative case research (Takim, 2005). The information obtained was cross-checked with company's information only from the annual reports due to the confidentiality.

\subsection{Background of Respondents}

Table 2 presents some details of the respondents' experience involved in the case studies. The number of respondents involved in this case study was six Human Resource officers. A total of 3 respondents $(50 \%, 3$ out of 6) had experience between 10 to 20 years; $33 \%$ ( 2 out of 6 ) of them had 1 to 10 years of working experience and followed by $17 \%$ ( 1 out of 6 ) of the respondents had more than 20 years of working experience. Based on the designation and work experiences of the respondents, it is sensible to infer that the majority of the respondents have a sound knowledge in Human Resource practices of their respective companies. The longer the experience of the respondent in construction company the greater their understanding of employees outcomes and influences.

Table 2. Profile of respondents and their experiences

\begin{tabular}{llcc}
\hline Type of Respondents & Company & Interview Respondents & Experience \\
\hline Admin Executive & Company A & 1 & 9 \\
Manager & Company B & 1 & 10 \\
Group Head of HR and Admin & Company C & 1 & 27 \\
Senior Manager & Company D & 1 & 20 \\
Executive & Company E & 1 & 6 \\
Senior Manager & Company F & 1 & 16 \\
\hline
\end{tabular}

\section{Results of Measuring Level of Technological Capabilities in TT Projects}

To identify the level of technological capabilities of the companies, the study attempts to develop a framework of technological capabilities in TT in construction organisation based on the experience learned from Indonesia, Japan \& Netherlands, United State of America and Malaysia. It highlighted three remarkable points: production performance, technology utilisation and firm's capability.

\subsection{Production Performance}

As mentioned by Company B,

"The level of technological capabilities of my organisation is rated as good. As a technical person, TT is an opportunity to learn a new technology. For contractors, the key factors are time and cost, meaning to say to reduce time taken to complete the project and subsequently reduce the cost. If we can shorten the time, we can reduce the overhead. There is no need to employ so many people and pay them for 5 years. Therefore when the duration is less, we can save on construction cost" (Company B-HR).

The statement above seems to match the results illustrated on Table 3. The level of technological capabilities can be measured based on reducing construction time and cost. Once the absorptive capacity is captured, subsequently will improve technological capabilities in terms of time and cost reduction of a TT project. Cross examination with other questions that were asked during the interviews indicated that construction time and cost could be reduced when the level of technological capabilities are enhanced. 
Table 3. Results of the production performance in technological capabilities in construction organisations (company A, B, C, D, E and F)

\begin{tabular}{|c|c|c|c|c|c|c|c|c|c|c|c|c|}
\hline \multirow[t]{2}{*}{ Level of Technological Capabilities } & \multicolumn{2}{|c|}{ Company A } & \multicolumn{2}{|c|}{ Company B } & \multicolumn{2}{|c|}{ Company $\mathrm{C}$} & \multicolumn{2}{|c|}{ Company D } & \multicolumn{2}{|c|}{ Company E } & \multicolumn{2}{|c|}{ Company $\mathrm{F}$} \\
\hline & Inc. & Dec. & Inc. & Dec. & Inc. & Dec. & Inc. & Dec. & Inc. & Dec. & Inc. & Dec. \\
\hline \multicolumn{13}{|l|}{ Production Performance } \\
\hline -Construction Cost & & $\sqrt{ }$ & & $\sqrt{ }$ & & $\sqrt{ }$ & & $\sqrt{ }$ & & $\sqrt{ }$ & & $\sqrt{ }$ \\
\hline -Construction time & & $\sqrt{ }$ & & $\sqrt{ }$ & & $\sqrt{ }$ & & $\sqrt{ }$ & & $\sqrt{ }$ & & $\sqrt{ }$ \\
\hline -Product quality - defects & & $\sqrt{ }$ & & $\sqrt{ }$ & & $\sqrt{ }$ & & $\sqrt{ }$ & & $\sqrt{ }$ & & $\sqrt{ }$ \\
\hline -Safety on construction site - accidents & & $\sqrt{ }$ & & $\sqrt{ }$ & & $\sqrt{ }$ & & $\sqrt{ }$ & & $\sqrt{ }$ & & $\sqrt{ }$ \\
\hline -Productivity & $\sqrt{ }$ & & $\sqrt{ }$ & & $\sqrt{ }$ & & $\sqrt{ }$ & & $\sqrt{ }$ & & $\sqrt{ }$ & \\
\hline -Profitability & $\sqrt{ }$ & & $\sqrt{ }$ & & $\sqrt{ }$ & & $\sqrt{ }$ & & $\sqrt{ }$ & & $\sqrt{ }$ & \\
\hline -Client Satisfaction & $\sqrt{ }$ & & $\sqrt{ }$ & & $\sqrt{ }$ & & $\sqrt{ }$ & & $\sqrt{ }$ & & $\sqrt{ }$ & \\
\hline
\end{tabular}

Moreover, Company $\mathrm{C}$ stated that:

"In my opinion the level of technological capabilities of this company depends on the capability of the employees. However for the company to train its workers in order to reach a high level of capability, they need to spend more money. In other words, it needs to have a budget for training" (Company C-HR).

Meanwhile, according to Company A,

"After TT, yes to a certain extent, definitely the level of technological capabilities is improved. The defect will be reduced. We must upgrade our quality and that is where guarantee comes in. For instance, at KLIA, there is a design guarantee of 5 years. In the case of a collapse or others, the client will be protected" (Company A-HR).

Once again as indicated by Company A:

"We want to ensure that the project can be delivered on time while the quality is not compromised. There must be no complaints from the clients. We must maintain our track record. We are not a one cent company" (Company A-HR).

The statements above confirmed that construction time and cost are vital in development of technological capabilities in construction industry (Wei, 1995; Smook and van Egmond, 2001). However, according to Wei (1995) although TT can be generally assumed that the technology importer could saves time and cost of the construction by importing advanced technology abroad in the long run, but that is not always the case. To a certain extent, despite high cost involved in TT projects, the quality is incomparable.

The structure of technological capabilities has four dimensions namely technology assets (equipment, information systems, software, personnel knowledge and know-how); organisational integration for technology assets: the external networks of technology and innovation knowledge; technology strategy (Xiaoqing and Qingrui, 2002). The knowledge in the production performance is mostly codified knowledge which is embedded into equipment, drawing, and procedure of production management. Therefore, most knowledge acquired from external sources is codified knowledge, and the best way of acquiring those is equipment importing (Xiaoqing and Qingrui, 2002). Thus, the systematic way of technology importing in construction organisation could improve product quality.

Regarding client satisfaction, Company $\mathrm{C}$ asserted that:

"Construction is not the same as Factory (manufacturing). After installation, we hand it over to the client and the client will be satisfied. After receiving our payment, our client will be satisfied. I dare not say that our performance is excellent but so far, there have not been reports of complaints" (Company F-HR).

The statement above shows that client's satisfaction is inevitable in measuring the levels of technological capabilities in TT projects. According to van Egmond and Vries (2008), technology needs are seen as a client requirement and satisfaction for products and services of the construction market. This requirements and satisfaction determine the range of process technologies that could be applied to produce the preferred products and services. Client requirements and satisfaction could be viewed through the project objectives, expectation, needs and wishes.

In terms of productivity and profitability, Company $\mathrm{E}$ indicated that: 
"Technologies may help to improve level of productivity. In terms of level of productivity and profitability of my company, it can be rated as good and employees' capabilities are improved from time to time. At the same time, the work ethics have improved too. The improvement in these factors have reflects on the overall performance of the company. If you ask me about accidents and number of fatality in TT projects, sorry I cannot reveal because it is too confidential" (Company E-HR).

Productivity of a company is measured by employees' turnover. The higher the employees' turnover of the company may indicate that the level of productivity is reduced. Hence, technological capabilities of the firms could be eroded due to the high level of employees' turnover of the company. This is related to work ethics as mentioned by Company E above.

In addition, safety at work is a complex phenomenon in the construction industry. Accidents could occur either due to lack of knowledge or training, a lack of supervision or a lack of means to carry out the task safely, carelessness, and absolute irresponsibility (Sawacha et al. 1999). In this respect, lack of technological capabilities in handling projects could results increase number of accidents in TT projects. A study conducted by Sawacha et al. (1999) reckons seven factors influence safety in construction. These are: historical, economical, psychological, procedural, technological capabilities, organisational and environmental issues. Hence, it proves that productivity, profitability and safety at site could be used to measure the level of technological capabilities in TT projects and in line with the opinion of Smook and van Egmond, (2001).

\subsection{Technology Utilisation}

Technological capabilities are measured based on: labour workforce and organisation \& management. Based on the results illustrated in Table 4, all the Companies (A to F) are having appropriate numbers of management professionals, skilled and unskilled technical staff and skilled and unskilled workers on site. Labour workforce is defined as the on-site workforce employed by contractors, and deemed to include all levels from senior management (skilled and unskilled) to operatives. With the increasing complexity of modern construction projects, demand for efficient and competent managers in the industry grows.

Table 4. Results of the technology utilisation in technological capabilities in construction organisations (company A, B, C, D, E and F)

\begin{tabular}{|c|c|c|c|c|c|c|c|c|c|c|c|c|}
\hline \multirow{2}{*}{$\begin{array}{l}\text { Level of } \\
\text { Technological } \\
\text { Capabilities }\end{array}$} & \multicolumn{2}{|c|}{ Company A } & \multicolumn{2}{|c|}{ Company B } & \multicolumn{2}{|c|}{ Company $\mathrm{C}$} & \multicolumn{2}{|c|}{ Company D } & \multicolumn{2}{|c|}{ Company E } & \multicolumn{2}{|c|}{ Company F } \\
\hline & $\begin{array}{l}\text { Type } \\
\text { of } \\
\text { labour }\end{array}$ & $\begin{array}{c}\text { Model } \\
\text { used }\end{array}$ & $\begin{array}{l}\text { Type } \\
\text { of } \\
\text { labour }\end{array}$ & $\begin{array}{c}\text { Model } \\
\text { used }\end{array}$ & $\begin{array}{l}\text { Type } \\
\text { of } \\
\text { labour }\end{array}$ & $\begin{array}{l}\text { Model } \\
\text { used }\end{array}$ & $\begin{array}{l}\text { Type } \\
\text { of } \\
\text { labour }\end{array}$ & $\begin{array}{l}\text { Model } \\
\text { used }\end{array}$ & $\begin{array}{l}\text { Type } \\
\text { of } \\
\text { labour }\end{array}$ & $\begin{array}{l}\text { Model } \\
\text { used }\end{array}$ & $\begin{array}{l}\text { Type } \\
\text { of } \\
\text { labour }\end{array}$ & $\begin{array}{c}\text { Model } \\
\text { used }\end{array}$ \\
\hline $\begin{array}{l}\text { Technology } \\
\text { Utilization }\end{array}$ & & & & & & & & & & & & \\
\hline $\begin{array}{l}\text {-Labour force } \\
\text {-Organisation }\end{array}$ & $\sqrt{ }$ & & $\sqrt{ }$ & & $\sqrt{ }$ & & $\sqrt{ }$ & & $\sqrt{ }$ & & $\sqrt{ }$ & \\
\hline $\begin{array}{l}\text { and } \\
\text { Management }\end{array}$ & & $\times$ & & $x$ & & $\times$ & & $\times$ & & $\times$ & & $\times$ \\
\hline
\end{tabular}

As mentioned by Company A:

"I could say that the levels of technological capabilities of my employees in TT projects (such as when we undertake projects in Saudi Arabia) are improved since I employed many skilled project managers and engineers, local and abroad. Expert employees are able to captured high level of new information and techniques of construction quickly. "(Company A-HR)

The statement implies that technology utilisation could be measured based on appropriate numbers of management professionals, skilled and unskilled technical staff and skilled and unskilled workforce.

In addition, Company $\mathrm{C}$ asserted that:

"We do not have a specific management model in undertaking any projects including overseas projects. We do projects based on company's aim, objectives, and mission. We welcome good management model but to a certain extent it is difficult to implement" (Company C-HR).

The statement clearly implies that most Mega companies do not apply any specific management model in implementing TT projects.

\subsection{Firm's Capabilities}

Table 5 presents the results of firm's capabilities in technological capabilities in Company A, B, C, D, E and F. Firm's capabilities are measured based on: tools, research input and development output as suggested by Smook 
\& Van Egmond (2001). As in indicated by Company E,

"In this project we don't have so much new technologies. But, we have tunneling work which requires the buying of new machines. After a short period of training, our staff can operate the machine tunneling work. We usually purchase our equipment from abroad; therefore training for using this equipment is learned comprehensively for a period of between 1-3 months. Then, things are totally left to us. The involvement of foreigners is mostly on the management level, whereas for the operational level, it will be handled by our local employees." (Company E-HR).

The above statement implies that purchasing new equipments in TT projects could help the transfer of technological capabilities from abroad into local organisations which is in line with the idea of Ofori (1994). According to him importing new equipments by organisations could involves technological change occurred in that organisations and ultimately has a greater influence on the company's performances.

Table 5. Results of the firms capabilities in technological capabilities in construction organisations (company A, $\mathrm{B}, \mathrm{C}, \mathrm{D}, \mathrm{E}$ and F)

\begin{tabular}{|c|c|c|c|c|c|c|c|c|c|c|c|c|c|c|c|c|c|c|}
\hline \multirow{2}{*}{$\begin{array}{l}\text { *Level of } \\
\text { Technologica } \\
\text { 1 Capabilities }\end{array}$} & \multicolumn{3}{|c|}{ Company A } & \multicolumn{3}{|c|}{ Company B } & \multicolumn{3}{|c|}{ Company C } & \multicolumn{3}{|c|}{ Company D } & \multicolumn{3}{|c|}{ Company E } & \multicolumn{3}{|c|}{ Company F } \\
\hline & $\begin{array}{c}* \text { Inc } \\
.\end{array}$ & $\begin{array}{c}\text { Imp. } \\
\text { tool } \\
\mathrm{s}\end{array}$ & $\begin{array}{l}\text { R } \\
\& \\
\mathrm{D}\end{array}$ & $\begin{array}{l}\text { In } \\
\mathrm{c}\end{array}$ & $\begin{array}{c}\text { Imp. } \\
\text { tool } \\
\mathrm{s}\end{array}$ & $\begin{array}{l}\mathrm{R} \\
\& \\
\mathrm{D}\end{array}$ & $\begin{array}{c}\text { Inc } \\
.\end{array}$ & $\begin{array}{c}\text { Imp. } \\
\text { tool } \\
\mathrm{s}\end{array}$ & $\begin{array}{l}\mathrm{R} \\
\& \\
\mathrm{D}\end{array}$ & $\begin{array}{c}\text { Inc } \\
\text {. }\end{array}$ & $\begin{array}{c}\text { Imp. } \\
\text { tool } \\
\mathrm{S}\end{array}$ & $\begin{array}{l}\text { R } \\
\& \\
D\end{array}$ & $\begin{array}{c}\text { Inc } \\
.\end{array}$ & $\begin{array}{c}\text { Imp. } \\
\text { tool } \\
\mathrm{s}\end{array}$ & $\begin{array}{l}\mathrm{R} \\
\& \\
\mathrm{D}\end{array}$ & $\begin{array}{c}\text { Inc } \\
.\end{array}$ & $\begin{array}{c}\text { Imp. } \\
\text { tool } \\
\mathrm{s}\end{array}$ & $\begin{array}{l}\text { R } \\
\& \\
D\end{array}$ \\
\hline $\begin{array}{l}\text { Firms } \\
\text { Capabilities }\end{array}$ & & & & & & & & & & & & & & & & & & \\
\hline -Tools & & $x$ & & & $\sqrt{ }$ & & & $x$ & & & $\sqrt{ }$ & & & $\sqrt{ }$ & & & $\sqrt{ }$ & \\
\hline $\begin{array}{l}\text {-Research } \\
\text { Input }\end{array}$ & $\sqrt{ }$ & & & $\sqrt{ }$ & & & $\sqrt{ }$ & & & $\sqrt{ }$ & & & $\sqrt{ }$ & & & $\sqrt{ }$ & & \\
\hline $\begin{array}{l}\text {-Developmen } \\
\text { t output }\end{array}$ & & & $x$ & & & $x$ & & & $x$ & & & $x$ & & & $x$ & & & $x$ \\
\hline
\end{tabular}

Under the 'research input' and 'development output (R\&D)', Company A indicated that:

"In the last 5 years, due to the global economic fluctuations, it is quite difficult to sustain local and overseas project. Nevertheless, we are fortunate to secure one or two Mega projects abroad through E-tendering (i.e., in Saudi Arabia and Qatar)" (Company A-HR)

The statement above shows that it is difficult for Companies to secure overseas projects in the last 5 years. Due to its difficulty could affect the process of sustaining TT in local construction projects. This corroborate by Ofori (1994) stating that TT is an affordable short-cut to the development of local technological capabilities and improves economic efficiency, hence without sustaining continuous imported projects could jeopardise further development of technological capabilities in Malaysian construction industry.

Once again Company A emphasised:

"Normally, many construction companies are not allocating a special unit of in-house Research \& Development $(R \& D)$ compared to manufacturing industries. To a certain extent contractors are not oblige to have a in-house $R \& D$ because projects are on-off and $R \& D$ process may take a longer time and higher cost" (Company A-HR)

This may suggest that R \& D and buying results of R \& D work are not a preference among contractors' company. Although $\mathrm{R} \& \mathrm{D}$ is not a preference, it does not mean technology cannot be transferred into organisations. It is part of the constraints in TT projects but not a severe case (Akhavan et al. 2008).

Once again it is observed that by using the variables/rubrics for measuring the level of technological capabilities in TT projects could reveal coherent results. Noticeably, all the answers given by the respondents shown that knowledge, skilled and tools have been transferred via TT projects into organisations. In lieu to that the level of technological capabilities of the employees can be inferred through increased in production performance, technology utilisation and firms' capabilities of the companies. Among the six companies, the level of technological capabilities of Company B, D \& F are more excel in terms of the organisations capabilities as illustrated in Table 3, 4 and 5.

\section{Conclusion}

The findings revealed that, the proposed framework for measuring the level of technological capabilities in TT projects are production performance (i.e., construction cost, time, product quality, safety, productivity, profitability, and client satisfaction); technology utilisation (i.e., labour force and organisation \& management); 
and firm's capability (i.e., tools \& equipment, research input and development output).

In conclusion, as an organisation, a company has to change its internal structure and formulate new pertinent strategies to face external challenges. Understanding the employees' capability and capacity will help to identify the needs, requirements, and the level of technological capabilities of the company. A well developed company can defeat many of the internal and external barriers or obstacles to technology acquisition and utilisation in TT process. A company with the experience in TT projects will be familiar with the process of TT. The company that has dealings with a number of TT projects (having more experience) will perform better than those companies with less experience. To succeed in a TT process, it is pertinent for employers to engage a more skilled and qualified employees to obtain a high success rate in the level of absorptive capacity and technological capabilities of the construction organisations. From the proposed framework, it can deduce that the level of technological capabilities in TT projects could be measured. A detailed analysis in this study shows that those variables/rubrics emerged from this framework is appropriate for the Malaysian construction industry.

The research attempts to investigate Technology Transfer (TT) and development of technological capabilities in Malaysian Constructions Industry which reinforces the issues of measuring the level of absorptive capacity and level of technological capabilities in TT projects. The outcomes of the study could provide an insight in Malaysian construction project development and will hopefully provide valuable guidelines, especially to public or private sectors in Malaysia with regards to TT.

The research presented in this paper is part of an ongoing $\mathrm{PhD}$ research at Faculty of Architecture, Planning and Surveying, UiTM to develop a framework of technology transfer (TT) and measuring level of technological capabilities in Malaysian construction industry. The result of the study could provide an insight into the Malaysian construction project development and provide valuable guidelines, especially to the public or private sectors in Malaysia.

\section{Acknowledgements}

The authors would like to thank Universiti Tun Hussein Onn Malaysia for supporting the research under the Short Term Research Grant for the provided data in proceeds of this research.

\section{References}

Abu-Bakar, A. H. (2004). Factors Affecting Technology Transfer to Indigenous Construction Companies in Developing Countries in the Period 1984-1994: The Malaysian Experience. (Doctoral Dissertation, University College London).

Akhavan, A. N., Bagheri, A., \& Jabbari, N. (2008). An empirical studying of barriers for technology transfer: The case of Iran. Proceedings of the 2008 IEEE ICMIT, pp. 92-97.

Bell, M. (1987). The acquisition of imported technology for industrial development: Problem of strategies and management in Arab region. Baghdad: ESCWA, United Nations University.

Biggs, T., Shah, M., \& Srivastava, P. (1995). Technological capabilities and learning in African enterprises. RPED Working Paper AFT288, World Bank, Regional Program on Enterprise Development, Washington, DC.

Cusumano, M. A., \& Elenkov, D. (1994). Linking international technology transfer with strategy and management: a literature commentary. Research Policy, 23, 195-215. http://dx.doi.org/10.1016/0048-7333(94)90053-1

Dutta, S., Narasimhan, O., \& Rajiv, S. (2005). Conceptualizing and measuring capabilities: Methodology and empirical application. Strategic Management Journal, 26(3), 277-285. http://dx.doi.org/10.1002/smj.442

Fichman, R. G., \& Kemerer, C. F. (1997). Object technology and reuse: lessons from early adopters. IEEE Computer Society, 30(10), 47-59. http://dx.doi.org/10.1109/2.625304

Ghang, Z. (2010). From Transferred Technology to Technological Capability: A Framework for Examining the Acquisition of Technological Capability by Chinese Enterprises. Retrieved May, 2010, from http://www.ifm.eng.cam.ac.uk/cim/imnet/papers2001/zhanggang.pdf

Kumar, V., Kunar, U., \& Persaud. A. (1999). Building technological capability through importing technology: the case of Indonesian manufacturing industry. Journal of technology transfer, 24(1), 81-96. http://dx.doi.org/10.1023/A:1007728921126

Minbaeva, D., Pedersen, T., Björkman, I., Fey, C. F., \& Park., H. J. (2003). MNC knowledge transfer, subsidiary 
absorptive capacity, and HRM. Journal of International Business Studies, 34, 586-599. http://dx.doi.org/10.1057/palgrave.jibs. 8400056

Ofori, G. (1994). Construction Industry Development: A Role of Technology Transfer. Construction, Management and Economic Journal, 2(5), 379-392. http://dx.doi.org/10.1080/01446199400000049

Rosenberg, N., \& Frischtak, C. (Eds.). (1985). International Technology Transfer: Concepts, measures, and comparisons. New York: Praeger.

Sawacha, E., Naoum, S., \& Fong, D. (1999). Factors affecting safety performance on construction sites. $\begin{array}{lllll}\text { International Journal of Project } & \text { Management, } & \text { 17(5), }\end{array}$ http://dx.doi.org/10.1016/S0263-7863(98)00042-8

Schoenecker, T., \& Swanson, L. (2002). Indicators of firm technological capability: validity and performance implications. Engineering Management, 49(1), 36-44.

Smook, R. A. F., \& Van Egmond, E. L. C. (2001). Measuring construction productivity, technological performance, capabilities and competitiveness. CIB World Building Congress, April 2001, Wellington, New Zealand, pp.1-12.

Van Egmond., E. L. C., \& Vries, S. K. D. (2008). Suistanable Construction Industry Development through International Transfer of Innovatibe Technologies. Retrieved December, 2008 from: www.googlescholar.com

Wallender III, H. V. (Ed.). (1979). Technology Transfer and Management in the Developing Countries: Company Cases and Policy Analyses in Brazil, Korea, Peru, and Tanzania. Cambridge: Ballinger Publishing Company.

Wei, L. (1995). International technology transfer and development of technological capabilities: a thoretical framework. Journal of Technology in Society, 103-120. http://dx.doi.org/10.1016/0160-791X(94)00028-C

Xiaoqing, Z., \& Qingrui, X. (2002). The Path of Technological Capability Evolution. Keyan Guanli, 23(1), 70-76. 